Article

\title{
Entrepreneurial Resources, Complementary Assets, and Platform Sustainability
}

\author{
Jianxin Ge and Tong $\mathrm{Li}^{*}$ \\ Business School, Central University of Finance and Economics, Beijing 100081, China \\ * Correspondence: 2014311391@email.cufe.edu.cn
}

Received: 14 June 2019; Accepted: 6 August 2019; Published: 12 August 2019

\begin{abstract}
This paper applies grounded theory to explore the formation of platform leadership and its reputation through a single case study analysis of a Chinese energy internet platform enterprise CZB (Che Zhu Bang). Initially, CZB was a follower in China's internet energy market. After clarifying and acquiring the entrepreneurial resources and the complementary assets it needed, CZB quickly established an energy internet platform and its platform leadership in two years. The research shows the mechanism by which the entrepreneurial resources and complementary assets affect the evolution of the platform leadership, the interaction between platform leadership and its reputation, and in the end, how platform reputation influences platform sustainability.
\end{abstract}

Keywords: complementary assets; grounded theory; platform leadership; platform reputation; entrepreneurial resources; platform sustainability

\section{Introduction}

With the development of the internet and information technology, more and more enterprises are using the strategy of developing a platform to compete in the market [1]. A number of companies, including Intel, Microsoft, and Cisco, have significant platform leadership performance, which has driven innovation and market growth and, in turn, promoted their reputations [2]. However, on a global scale, most platform enterprises decline rapidly at the early stage of establishment [3]. Thus, how to promote the sustainable development of a platform has become an important question that urgently needs to be answered. This leads us to explore the following questions: Where does the leadership of platform enterprise come from? What is the impact of platform leadership on platform reputation? How does a platform's reputation influence a platform's sustainability?

Platform leadership refers to the ability of one enterprise to dynamically influence the direction of the product development of a large number of third-party enterprises around the platform, and to organize and coordinate connections among the various parts of the platform ecosystem, aiming at ensuring common development of the entire platform ecosystem [4]. Generally speaking, platform leadership includes the influence, leadership ability, coordination ability, and control power of a platform [5]. According to resource-based theory, organizations compete with other organizations based on their own resources and capabilities [6,7]. Among the entrepreneurial resources of the enterprise, resources that are valuable, scarce, difficult to imitate, and irreplaceable can lead to differences in competitiveness; identifying, configuring, and orchestrating entrepreneurial resources can help enterprises to establish a sustainable competitive advantage [6]. In other words, entrepreneurial resources have important effects on the strategic control and status of the enterprise. In order to attain the corporate's goals, specific plans of how to allocate resources must be made, and entrepreneurs should commit the resources to search for a feasible and profitable business model [8]. For platform enterprises, the determination of entrepreneurial resources and the mechanism of their role in building platform leadership are worth exploring. In addition, the platform enterprise and its surrounding 
enterprises actually form an ecological system. In this ecosystem, complementary assets play key roles in the cooperation, cross-border innovation, and win-win symbiosis between various enterprises [9]. Therefore, the roles of complementary assets cannot be neglected in the study of the source of enterprise platform leadership.

Corporate reputation is an aggregation of organizational responses to the needs and expectations of numerous organizational stakeholders as perceived by stakeholders [10], including two dimensions: emotional reputation (generalized favorability) and cognitive reputation (being known) [11]. There are many factors that can affect corporate reputation, including product and service quality, corporate social responsibility, attractiveness, and corporate performance [12,13]. For platform enterprises, because of the separation of capital flow and logistics, consumers' trust in the platform has become an important factor affecting the reputation of platform enterprises [14]. In addition, the reputation of platform enterprises also has the dual structural characteristics of the individual reputation of platform enterprises and the reputation of the group of platform sellers [15]. The reputation of platform leaders is also affected by the reputation of other enterprises in the platform ecosystem. The improvement of the factors mentioned above requires enterprises to have sufficient resources and capabilities so as to obtain a certain status in the market and to meet the expectations of a large number of stakeholders. In order to protect the reputation of the enterprise and strengthen platform leadership, platform leaders need to have certain achievements in the provision of products and services to gain consumers' goodwill and trust, as well as corporate performance, status, and attraction, and to have a certain ability to coordinate and control the behavior of other enterprises in the platform ecosystem. These achievements and abilities are closely related to platform leadership.

Plenty of research shows that corporation sustainability is influenced by corporate reputation [16], as while a corporate has strong corporate reputations, its influence on corporate communications and social marketing public relations could be stronger and therefore benefit corporate sustainability $[16,17]$. In the case of platform enterprises, there is a lack of relevant research. Therefore, this paper will also answer the important question of how platform reputation affects platform sustainability.

To sum up, this paper proposes the following research questions: First, what factors influence the formation of platform leadership and how does the impact work? Second, what is the relationship between platform leadership and a platform's reputation? Third, how does a platform's reputation influence a platform's sustainability? Based on grounded theory, this paper studies the case of CZB (Che Zhu Bang), an internet energy platform in China, and explores the mechanisms that influence the platform reputation of the enterprise. The structure is as follows: In the first part, this paper defines the concepts of entrepreneurial resources, complementary assets, platform leadership, corporate reputation, and platform sustainability, and reputation theory is taken as the theoretical basis of this paper. The second part introduces the research method and analysis process. Subsequently, the paper discusses the research results, gives comments on the contributions of this paper, and provides possible future research directions.

\section{Concepts Definition}

\subsection{Entrepreneurial Resources}

According to resource-based theory, enterprises are a collection of heterogeneous resources, and the uniqueness of these resources is the basis for enterprises to obtain a competitive advantage and excess profits [18]. Entrepreneurial resources refer to the various elements and their combinations that can achieve the strategic objectives of a new enterprise in the process of providing products or services to society [6]. The general entrepreneurial resources are included in Table 1. 
Table 1. Entrepreneurial resources.

\begin{tabular}{|c|c|}
\hline First-Level Index & Second-Level Index \\
\hline Human resources & $\begin{array}{l}\text { (1) Educational background of employees; (2) Diversity of expertise } \\
\text { and background of employees; (3) Entrepreneurial talent; (4) } \\
\text { Entrepreneurial team; (5) The degree of difficulty in recruiting } \\
\text { high-quality personnel from outside; (6) Qualification and rigor of } \\
\text { employment. }\end{array}$ \\
\hline Reputation resources & $\begin{array}{l}\text { (1) The recognition of influential people in society; (2) Industry } \\
\text { status; (3) User loyalty; (4) Corporate social image. }\end{array}$ \\
\hline Capital resources & $\begin{array}{l}\text { (1) Initial self-owned capital; (2) Current capital; (3) Financing } \\
\text { channels and sources; (4) Ease of access to external funds, loans, and } \\
\text { investments; (5) Liabilities; (6) Revenue and earnings. }\end{array}$ \\
\hline Physical resources & $\begin{array}{l}\text { (1) Infrastructure construction; (2) Computer communication system; } \\
\text { (3) Property management and business center; (4) Transportation } \\
\text { and living facilities. }\end{array}$ \\
\hline
\end{tabular}

(1) The number of S\&T (Science and Technology) projects and achievements or patents; (2) Access to external S\&T assistance and

Science and technology resources S\&T achievements; (3) Whether a platform for the transformation of S\&T achievements has been established and has the ability to realize the commercialization of S\&T achievements; (4) Proportion of technical and research personnel.

(1) Entrepreneurial experience and management experience of

Organizational and management resources entrepreneurs; (2) Establishing a relatively advanced entrepreneurial knowledge management system; (3) Ease in obtaining various management consulting and planning services from the outside.

(1) Government investment and financing, fiscal, and taxation policies and preferential treatment; (2) Whether the government has

Policy resources formulated a more practical policy on entrepreneurship training and counselling; (3) Whether the government has introduced superior policies for the introduction of entrepreneurial talents.

(1) Access to information about the industry; (2) Availability of information about competitors, markets, and needs; (3) Availability

Information resources of public and proprietary product and technical information; (4) Availability of information on R\&D, procurement, manufacturing, marketing, and services.

Social resources

(1) Investors; (2) Organizations which provide support services (such as legal firms); (3) Policy makers; (4) Academicians; (5) Professional bodies; (6) Trade associations; (7) Media; (8) Public relation experts.

(Sources: Barney, 1991 [6]; Lin, 2007 [19]; Yu, 2013 [20]; Lin et al., 2005 [21]; Pan, 2014 [22]; Sarma and Sun, 2017 [23]; Sun and Zhang, 2015 [24]).

At the beginning of entrepreneurship, entrepreneurial resources are often scarce. It is very important for entrepreneurs to identify various entrepreneurial resources effectively and to organize and integrate them with the help of internal and external forces $[8,19]$. Among entrepreneurial resources, resources that are valuable, scarce, difficult to imitate, and irreplaceable can contribute a lot to establish a competitive advantage [6]. Entrepreneurial resources can lead to differences in competitiveness, and the identification, configuration, and orchestration of entrepreneurial resources can help enterprises to establish a sustainable competitive advantage [6]. Enterprises with resources that are difficult to imitate may obtain a sustainable and superior financial performance [25]. On the basis of the industry characteristics, key success factors, and asset specificity of the case enterprise $\mathrm{CZB}$, we conclude that the entrepreneurial resources of the case enterprise are capital resources, human resources, physical resources, policy, and legal resources. 


\subsection{Complementary Assets}

Complementary assets were proposed by Teece in the profiting from innovation (PFI) model, which refers to a series of professional manufacturing capabilities, distribution channels, service networks, complementary technologies, and other factors closely related to the commercialization of new technologies that are owned and controlled by enterprises in the process of innovation and marketization [26]. Teece believes that, in some cases, the technology pioneers occupy an absolute competitive advantage, but that in other cases, the latecomers can gain a larger market share. Even in the case of knowledge diffusion and imitation by competitors or followers, as long as enterprises have strong complementary assets, greater value can be created and thus more profits can be obtained compared with competitors with the same knowledge and technology [27]. Complementary assets are helpful for forming effective dynamic capabilities and competitive advantages, thus enabling the corporate to be more flexible so that it has a better chance of survival [23]. From the perspective of the platform, complementary assets may either hinder the development of the platform or encourage the development of the platform. At the same time, they can also attract the entry of new customers. These consumers will consume the core products while consuming supplements- the products in the industry that are centered around the platform product. In an industry centering on platform products, the more supplements there are, the higher the value of the platform will be [28].

Teece [21] distinguishes three different types of complementary assets in his conceptual framework: generic, specialized, and co-specialized. Generic complementary assets are not specifically used for innovation and can be traded on the market. Specialized complementary assets show unilateral dependence of innovation on complementary assets, while co-specialized complementary assets show bilateral dependence. Complementary assets may come from internal sources, for example, from the collaboration between enterprise departments, including the abilities, knowledge, and technologies possessed by employees [29]. They may also come from external sources, through strategic cooperation, alliance, or acquisition [30]. Therefore, we divide complementary assets into generic complementary assets and specialized complementary assets.

\subsection{Platform Leadership}

Leadership in inter-organizational networks such as platform ecosystems differs significantly from leadership in individual organizations [31,32]. Leadership in such networks requires orientation and guidance from a powerful organization [33]. Gawer and Cusumano first proposed the concept of platform leadership, believing that the platform leader is an enterprise that aims to promote innovation in its own industry [28]. Ensuring integrity and promoting the development of the platform are inevitable development strategies of the platform leader. A platform leader can benefit from the development and innovation of other companies, but also highly relies on the development and innovation of other companies in the platform ecosystem. Platform leadership refers to the ability of an enterprise to dynamically influence the product development direction of other enterprises by cooperating with a large number of third-party enterprises. The platform leader aims to ensure the development of the entire platform ecosystem [4]. The platform leader can have a huge impact on the direction of innovation in its industry, as well as the "ecosystem" built with companies and consumer networks that produce and use supplements. Lee et al. analyzed the five factors that can influence platform leadership: innovation ability, connectivity, complementarities, efficiency, and the positive network effect [1]. To sum up, in addition to having a certain status and influence, platform-leading enterprises should also have a certain ability to lead the innovation and development of other enterprises in the platform ecosystem, coordinating the relationship between enterprises in the ecosystem and pointing the development of the platform ecosystem in a sustainable direction. Cusumano and Gawer proposed that platform leaders need followers, which requires a certain leadership ability: leaders should desire to be on top, which indicates the influence of the leader; they should put their organizations in the best competitive position by mastering two tricks-coordinating internal units that play one or more of those roles and interacting effectively with outsiders playing those roles-which 
requires coordination ability; and should pursue consensus and control at the same time, which requires coordination ability [34]. Therefore, we subdivide platform leadership into four dimensions: influence, leading ability, coordination ability, and control power.

\subsection{Platform Reputation}

A platform ecosystem has the platform enterprise as its core, and has complementary providers on the periphery $[35,36]$. Therefore, a platform's reputation is actually about the reputation of the core enterprise.

Corporate reputation refers to the overall attractiveness of an enterprise's past behavior and future prospects to all its stakeholders compared with other leading competitors [37]. This includes three aspects: familiarity with an organization ("being known"), perceptions of the organization's overall favorability ("generalized favorability"), and expectations of the organization relevant to a specific audience ("being known for something") [38]. Corporate reputation is the sum of a series of characteristics generated by the past behavior of an enterprise, which can create a premium [39]. Thus, it is very important for the development of an enterprise. There are many factors affecting corporate reputation. Schwaiger classified the factors affecting corporate reputation into four categories: quality, performance, responsibility, and attractiveness [11].

Research on corporate reputation has attracted more attention for decades [10,38,40]. Corporate reputation is a kind of information about the characteristics of an organization-a precious resource that is scarce and inimitable. A good corporate reputation has strategic value for an enterprise [39,41,42], as it gives them a competitive advantage over many similar enterprises [6,43]. The existing empirical research results show that corporate reputation is highly correlated with corporate performance, and there is a positive correlation between reputation and financial performance [44,45]. Using two complementary dynamic models, Roberts and Dowling [46] conducted an analysis and found that companies with a relatively good reputation can better maintain excellent profit results over time. In addition, a good reputation will help an enterprise to attract more talented staff [47], reduce transaction costs [48], reduce the operational risk [49], and even have a positive impact on its legitimacy [50]. When an enterprise encounters obstacles in management, reputation can help it transform or gain favorable factors from other aspects [51]. Therefore, a good corporate reputation contributes to the sustainable development of enterprises [16]. The importance of corporate reputation to enterprises is self-evident.

Corporate reputation includes two dimensions: favorability and popularity. Favorability reflects the evaluation and judgment of stakeholders, while popularity reflects the non-evaluation recognition of stakeholders [11]. These two dimensions are conceptually different, as well-known companies may be loved or hated [38]. For example, through large-scale interviews with the public, Gardberg and Fombrun found that the most well-known companies might have the best reputation, the worst reputation, or both [52]. Hall defined corporate reputation as having two aspects: knowledge and emotions [53]. Therefore, we divide corporate reputation in this paper into two dimensions: emotional reputation (favorability) and cognitive reputation (popularity).

At present, there is a lack of research on the relationships among entrepreneurial resources, complementary assets, platform leadership, and platform enterprise reputation. Thus, further research on their interaction mechanism is needed.

\subsection{Platform Sustainability}

Sustainability refers to development that meets the needs without compromising the ability of future generations to meet their own needs $[16,54]$. According to the definition of sustainability, corporate sustainability can be defined as corporate enterprise's ability to balance the stakeholders' needs and meet the needs of its current stakeholders without compromising its ability to meet the needs of its future stakeholders [55]. The measurement of corporation sustainability should focus on three parts: economic performance, environment stewardship, and social wellbeing $[16,56]$. 
In this paper, we define the corporate sustainability of platform enterprises as platform sustainability, which is a special kind of corporate sustainability that should contain the same dimensions as corporate sustainability.

Economic performance works closely with shareholders' benefits and the stable operation and future development of corporates [16]. Therefore, it is an important predictor for platform sustainability.

From an environmental perspective, almost every enterprise has an environmental impact and can create waste and pollution [56]. Platform enterprises are no exception, and can have a major impact on the community, and even on the whole society. Therefore, platform enterprises should try their best to maintain sustainability by minimizing environmental impacts [57].

Platforms operate in the social environment. Therefore, they need to be socially responsible [58]. The objective of the social dimension of platform sustainability is to reduce the negative social impacts while in the meantime generating and enhancing positive social impacts $[16,56]$ and helping to solve social problems [59]. At present, there is a lack of research on platform sustainability, which makes this research of certain importance both in theory and practice.

\section{Methodology}

\subsection{Research Design}

The purpose of this study was to explore how entrepreneurial resources and complementary assets affect platform leadership and thus influence a platform's reputation, to reveal the formation process of a platform's reputation from the perspective of platform leadership, and to find out how a platform's reputation can affect its sustainability. We adopted the single case analysis method and grounded theory methodology [60]. The key idea of grounded theory research lies in multiple comparisons through gradual and concentrated steps so as to conceptualize data and refine more categories until the theory is saturated. According to the characteristic of grounded theory that establishes theory on the basis of empirical data, we first collected a large amount of textual data, mainly second-hand news reports obtained from the Internet, as well as materials obtained through interviews with the senior managers of the case enterprise, CZB. After that, we sorted and processed the range of materials collected, conducted open coding, axial coding, and selective coding on these data, put forward propositions according to induction, and, finally, formed a relationship model among entrepreneurial resources, complementary assets, platform leadership, corporate reputation, and platform sustainability.

In order to ensure the integrity and effectiveness of the study, we formed a material collection and analysis team composed of two university professors, two postgraduate students, and four undergraduate students, who were responsible for the collection of textual data and subsequent analysis of the case company.

\subsection{Background of the Case Company (CZB)}

Today, the supply of fossil energy is increasingly tight. The environmental and global climate problems caused by the use of fossil energy are becoming more and more serious. Human beings urgently need to change the traditional energy consumption pattern and consumption structure, and because of this, the development of a low-carbon economy, the development and utilization of new energy, and the transformation of traditional energy enterprises have become the consensus of all countries around the world [61]. The traditional pattern of economic and social development characterized by the centralized use of fossil energy is gradually changing, and the third industrial revolution, represented by new energy technologies and internet technologies, is emerging [62].

The increasingly extensive application of new energy and the development of internet energy platforms have brought changes to many industries. Driven by China's preferential policies on new energy vehicles, the automotive energy industry is facing great changes [63].

CZB was established in 2016 as a follower of China's energy industry in the beginning. It brought insights into the development trend of the automobile energy industry. Its business has developed 
rapidly, covering several cities in China, and it occupies the leading position in China's energy industry and has become China's leading commercial vehicle internet energy platform [64].

CZB has signed with more than 3000 gas stations, including state-owned and private ones, which are distributed in 55 cities all over the country. In terms of charging services, more than 200,000 charging piles have been installed, covering over 50 cities in China. In the meantime, CZB also provides a series of auxiliary services. CZB's vision is to build China's first platform using energy big data to improve the efficiency of the energy industry and change the industry's ecology [64]. The achievements of CZB are given below:

(1) Built the first commercial vehicle open internet energy platform that integrates refueling and charging services in China.

The early automobile internet energy platforms and commercial vehicle internet energy platforms in China mainly provide refueling price information or refueling discounts. None of them cooperate with charging pile operators, resulting in the separation of oil and electricity services.

When CZB entered the market, it integrated oil and electricity services for commercial vehicles on one platform. CZB cooperated with gas stations to provide a refueling discount service for commercial vehicle owners, and it later launched a charging service, integrating the services of new energy vehicle operators and charging operators to provide charging convenience for owners of new energy commercial vehicles, and then successfully constructed the first commercial vehicle open internet energy platform that integrates refueling and charging services in China.

(2) Became the leading domestic commercial vehicle energy supplier in China.

Currently, CZB is the largest integrated internet energy platform in China, providing services in 55 cities with a daily transaction volume of around 10 million yuan and nearly 2 million registered users. CZB attracts about 15,000 new users per day, and 59\% of new users repurchase the enterprise's products and services. By using CZB's products and services, a commercial vehicle's net profit can increase by $30 \%$.

(3) Built relationships with a large number of strategic partners to deeply connect the industrial chain and provide diversified services.

CZB provides diversified services for commercial vehicle owners through deep cooperation with a large number of partners in various fields related to commercial vehicles. Besides CZB's main services, such as refueling discounts, a commercial vehicle charging service, and a new energy commercial vehicle rental service, it also provides a series of auxiliary services. Thus, it provides a complete set of commercial vehicle services and has both depth and breadth, which is not currently given by other platform enterprises.

\subsection{Data Collection}

We mainly used second-hand materials in the study, which were obtained by team members through corporate websites, media interviews, relevant BBS (bulletin board systems), among other material, supplemented by certain primary materials, which were mainly obtained through informal interviews, platform experience, and other sources. Through collation, a large number of original textual materials were obtained, and the total number of words in the materials after collation was about 100,000 words.

\subsection{Data Reduction and Analytical Approach}

We sorted out the data from the case enterprise through data coding. The purpose was to extract research topics from textual data so as to construct the influence model of the platform's reputation. First, we conducted three-level coding for the original data. In the first level, we adopted the open coding method, in which the team members used back-to-back labeling to construct various categories until the theory was saturated. Axial coding was used for second level coding. This was based on the dimensions of each construct proposed above. Categories obtained in open coding were judged and classified. In third-level coding, categorization was performed again according to the constructs to which each dimension belonged. Finally, 243 valid entries were obtained, including 35 results of first-level coding, 15 results from second-level coding, and 5 results of third-level coding. Relevant constructs and their coding processes are shown in Table 2. 
Table 2. Constructs coding and examples.

\begin{tabular}{|c|c|c|c|c|}
\hline Third-Level Coding & Second-Level Coding & First-Level Coding & Classic Statement Reference & Count \\
\hline \multirow{9}{*}{ Entrepreneurial resources (SR) } & \multirow[t]{2}{*}{ Capital resources (CR) } & Financing (CR1) & $\begin{array}{l}\text { CZB (Che Zhu Bang) completed three rounds of over } 200 \\
\text { million yuan of financing within seven months at an } \\
\text { amazing speed. }\end{array}$ & 14 \\
\hline & & Revenue and earnings (CR2) & $\begin{array}{l}\text { At present, the daily turnover of CZB is around } 10 \text { million } \\
\text { yuan, which can maintain a compound growth of } 20 \% \text { per } \\
\text { month in } 2019 \text {, and the annual turnover of CZB can reach } 35 \\
\text { billion yuan in } 2019 \text {. }\end{array}$ & 13 \\
\hline & \multirow[t]{3}{*}{ Human resources (HR) } & $\begin{array}{l}\text { CEO (Chief Executive Officer) } \\
\text { (HR1) }\end{array}$ & $\begin{array}{l}\text { As the owner and founder of CZB, Dai Zhen has much } \\
\text { entrepreneurial experience and many years of operation } \\
\text { and management experience. }\end{array}$ & 10 \\
\hline & & Entrepreneurial team (HR2) & $\begin{array}{l}\text { Among his team, } 46 \text { percent are born in the } 1990 \text { s and only } \\
\text { six are born in the } 1970 \text { s. Such a team is created by the } \\
\text { market, which represents the energy internet and the } \\
\text { characteristics of the internet industry. }\end{array}$ & 3 \\
\hline & & Employees (HR3) & $\begin{array}{l}\text { I am a restless, warm-hearted and responsible person. } \\
\text { When anything happens, I like to solve the problem and } \\
\text { help everyone at once. }\end{array}$ & 5 \\
\hline & \multirow[t]{3}{*}{ Physical resources (PR) } & Gas stations (PR1) & $\begin{array}{l}\text { CZB has signed contracts with more than } 3000 \text { gas stations, } \\
\text { including Shell, Sinochem, Daqiao petrochemical, } \\
\text { Zhongcheng, Zhongyuan, Zhongtu energy, Zhongneng } \\
\text { petrochemical, Jixing petroleum, and others. }\end{array}$ & 3 \\
\hline & & Charging piles (PR2) & $\begin{array}{l}\text { CZB has installed } 150,000 \text { charging piles, accounting for } 65 \% \\
\text { of the total number of public charging piles, covering more } \\
\text { than } 50 \text { cities. }\end{array}$ & 3 \\
\hline & & $\begin{array}{c}\text { New energy commercial } \\
\text { vehicles (PR3) }\end{array}$ & $\begin{array}{l}\text { Following the launch of four new energy logistics vehicles } \\
\text { in June, on } 17 \text { July, the leasing section of the CZB platform } \\
\text { newly launched the Geely long-range E200 model in } \\
\text { Shenzhen, Guangzhou, and Chengdu, providing electric } \\
\text { vehicle sharing, rental purchase, and other services for } 32 \\
\text { million commercial vehicle drivers in China. }\end{array}$ & 3 \\
\hline & Policy and legal resources (LR) & New energy policy (LR1) & $\begin{array}{l}\text { The policy of "loosening restrictions" on foreign investment } \\
\text { will accelerate the development and promotion of whole } \\
\text { new energy vehicles, and also promote the development of } \\
\text { the commercial vehicle market. }\end{array}$ & 11 \\
\hline
\end{tabular}


Table 2. Cont

\begin{tabular}{|c|c|c|c|c|}
\hline Third-Level Coding & Second-Level Coding & First-Level Coding & Classic Statement Reference & Coun \\
\hline \multirow{4}{*}{ Complementary assets (CA) } & \multirow[t]{2}{*}{ Specialized assets (SA) } & Learned (SA1) & $\begin{array}{l}\text { From trying to solve the problem of high fuel cost in the logistics industry, to } \\
\text { building a centralized procurement platform for commercial vehicles, to } \\
\text { entering the energy big data and energy blockchain and preparing to build } \\
\text { an energy ecological chain, CZB keeps "upgrading" its business model. }\end{array}$ & 3 \\
\hline & & Accumulated (SA2) & $\begin{array}{l}\text { By making use of big data sharing and interconnection, CZB gets through } \\
\text { the energy circulation network and establishes a new energy system with } \\
\text { high integration of energy and information. }\end{array}$ & 6 \\
\hline & \multirow[t]{2}{*}{ Generic assets (GA) } & Market-acquired (GA1) & $\begin{array}{l}\text { We basically have no fixed assets on our platform, and we lease computers } \\
\text { and other equipment from the market. }\end{array}$ & 2 \\
\hline & & Cooperatively acquired (GA2) & $\begin{array}{l}\text { CZB's main business includes discount refueling, and cooperation with other } \\
\text { brands to open a one-stop platform for car owners' service, providing } \\
\text { services that include inspection and payment of violation, tire service, } \\
\text { automobile purchase, Car washing, car insurance, maintenance, and other } \\
\text { services for car owners. }\end{array}$ & 42 \\
\hline \multirow{11}{*}{ Platform leadership (PL) } & \multirow[t]{3}{*}{ Platform influence power (PI) } & $\begin{array}{l}\text { Take the lead in demonstrations } \\
\text { (PI1) }\end{array}$ & $\begin{array}{l}\text { By using big data and other technologies, we can change the mode of energy } \\
\text { transaction, break the monopoly of the energy industry, create a new pattern } \\
\text { of energy ecology, and become the "operating system" of the energy industry. }\end{array}$ & 10 \\
\hline & & Status and authority (PI2) & $\begin{array}{l}\text { According to the latest data released by CZB, CZB is the industry leader in } \\
\text { terms of size, and its "unicorn" status of the industry is self-evident. }\end{array}$ & 13 \\
\hline & & Goal achievement (PI3) & $\begin{array}{l}\text { Centering on the user demand, the new energy logistics time-sharing leasing } \\
\text { platform is further built. The technology realizes energy optimization and } \\
\text { CZB realizes the "crazy idea". }\end{array}$ & 13 \\
\hline & \multirow{3}{*}{ Platform leading ability (PL) } & Members follow (PL1) & $\begin{array}{l}\text { Now a lot of branded gas stations have actively sought CZB, hoping to } \\
\text { quickly participate in this business model. }\end{array}$ & 3 \\
\hline & & Strain capacity (PL2) & $\begin{array}{l}\text { The large size is the most obvious advantage of CZB to deter competitors, } \\
\text { but from a dynamic process, this is the result of another advantage of CZB, } \\
\text { namely CZB's "redefining energy retail" and "omnipresent" service } \\
\text { capability. }\end{array}$ & 5 \\
\hline & & Control of strategy (PT3) & $\begin{array}{l}\text { Relatively speaking, no internet company like CZB is precisely targeted for } \\
\text { commercial vehicles (express, taxi, truck). }\end{array}$ & 8 \\
\hline & \multirow[t]{3}{*}{$\begin{array}{l}\text { Platform coordination ability } \\
\qquad(\mathrm{PH})\end{array}$} & Task coordination (PH1) & $\begin{array}{l}\text { SaaS (Software-as-a-Service) management at the gas station can help the gas } \\
\text { station to complete tasks, such as accounting, sales, and fuel management. } \\
\text { The team OS (operating system) can help the logistics platform manage the } \\
\text { team. }\end{array}$ & 3 \\
\hline & & Relationship coordination ( $\mathrm{PH} 2)$ & $\begin{array}{l}\text { After locking in the price of refined oil, through cooperation with major } \\
\text { logistics platforms, CZB locks in the truck drivers in advance and gives them } \\
\text { the profit margin. }\end{array}$ & 6 \\
\hline & & Goal drive (PH3) & $\begin{array}{l}\text { While improving the profit margin of commercial vehicle drivers as much as } \\
\text { possible, CZB further excavates the depth of its services. }\end{array}$ & 11 \\
\hline & \multirow[t]{2}{*}{ Platform control power (PC) } & Behavior control (PC1) & $\begin{array}{l}\text { CZB and the cooperation platform get through the technology and data, and } \\
\text { realize the unique interface to lock the transaction. }\end{array}$ & 1 \\
\hline & & Business control (PC2) & $\begin{array}{l}\text { We lock in the price of oil products and invest money to buy them first and } \\
\text { then sell them to our downstream customers. }\end{array}$ & 3 \\
\hline
\end{tabular}


Table 2. Cont

\begin{tabular}{|c|c|c|c|c|}
\hline Third-Level Coding & Second-Level Coding & First-Level Coding & Classic Statement Reference & Count \\
\hline \multirow{5}{*}{ Corporate reputation (CR) } & \multirow[t]{2}{*}{ Cognitive reputation (CR) } & $\begin{array}{l}\text { Reputation in the industry } \\
\text { (CR1) }\end{array}$ & $\begin{array}{l}\text { CZB was previously known in the industry as a potential } \\
\text { stock; now, CZB is favored by the capital with the strength } \\
\text { of the dark horse of energy. }\end{array}$ & 10 \\
\hline & & Reputation among users (CR2) & $\begin{array}{l}\text { More than } 60 \% \text { of drivers know and even use it frequently } \\
\text { for refueling. }\end{array}$ & 3 \\
\hline & \multirow[t]{3}{*}{ Emotional reputation (ER) } & $\begin{array}{l}\text { Favorable impression brought } \\
\text { by economic benefit (ER1) }\end{array}$ & $\begin{array}{l}\text { "Fuel with a discount, CZB!"- - the slogan is not only deeply } \\
\text { rooted in the hearts of the people, but, for users, CZB has } \\
\text { been a money saver they cannot live without. }\end{array}$ & 7 \\
\hline & & $\begin{array}{l}\text { Favorable impression brought } \\
\text { by convenience (ER2) }\end{array}$ & $\begin{array}{l}\text { CZB successfully solved the "pain points", such as } \\
\text { "unreasonable layout, closed platform, and weak brand } \\
\text { influence" of the charging pile industry, bringing multiple } \\
\text { surprises to the owners of new energy vehicles. }\end{array}$ & 4 \\
\hline & & $\begin{array}{l}\text { Favorable impression brought } \\
\text { by feelings (ER3) }\end{array}$ & $\begin{array}{l}\text { Only Dai Zhen is bent on helping a group of bottom } \\
\text { workers ("commercial vehicle drivers") to save money. He } \\
\text { is just like the mother of these drivers, worrying about the } \\
\text { livelihood of his "children" every day. }\end{array}$ & 2 \\
\hline \multirow{6}{*}{ Platform sustainability (PS) } & \multirow[t]{2}{*}{ Economic performance (EP) } & Market share (EP1) & $\begin{array}{l}\text { Currently, CZB is the largest integrated energy internet } \\
\text { platform in China, providing services in } 55 \text { cities with } \\
\text { nearly } 2 \text { million registered users. CZB attracts about } 15,000 \\
\text { new users per day, and } 59 \% \text { of new users repurchase. }\end{array}$ & 5 \\
\hline & & Income and profit (EP2) & $\begin{array}{l}\text { The daily transaction volume of CZB is around } 10 \text { million } \\
\text { yuan. }\end{array}$ & 5 \\
\hline & \multirow[t]{2}{*}{ Environment stewardship (ES) } & Improve energy efficiency (ES1) & $\begin{array}{l}\text { If CZB can promote commercial vehicles and platform } \\
\text { through the combination of online community and offline } \\
\text { retail, allow the driver to easily find a gas station, and let the } \\
\text { gas station service drivers in the most efficient way, to form } \\
\text { a closed loop, the whole chain of data online can improve } \\
\text { fuel efficiency and optimize the unnecessary energy loss. }\end{array}$ & 6 \\
\hline & & Promote new energy (ES2) & $\begin{array}{l}\text { At present, CZB has established cooperative partnership } \\
\text { with well-known new energy vehicle enterprises to further } \\
\text { empower new energy vehicles. }\end{array}$ & 3 \\
\hline & \multirow[t]{2}{*}{ Social wellbeing (SW) } & $\begin{array}{l}\text { Reduce working pressure of } \\
\text { drivers (SW1) }\end{array}$ & $\begin{array}{l}\text { By using CZB's products and services, commercial vehicles' } \\
\text { net profit can increase by } 30 \% \text {. }\end{array}$ & 4 \\
\hline & & Public welfare behavior (SW2) & $\begin{array}{l}\text { On the afternoon of May 26, Chen Long, the Wenzhou city } \\
\text { manager of CZB, came to the home of Liu Wenzhong, the } \\
\text { "road hero", and presented him with a banner and provided } \\
\text { him with the annual refueling fee for free. }\end{array}$ & 2 \\
\hline
\end{tabular}


As shown in the table above, we conducted the identification of the entrepreneurial resources of the case company CZB using a large amount of second-hand data and part of the interview data, and the following findings were made: First, high-tech, capital-intensive industries, such as internet energy platforms, feature high capital expenditure [65]. CZB also has the characteristic of a fast financing speed. In order to ensure the survival and rapid development of the enterprise among the fierce market competition, CZB needs continuous financial support to realize its strategy, so capital resources are one of the important entrepreneurial resources of CZB.

Second, continuous innovation is the main means for organizations to keep growing, and human resources are a key resource to help organizations learn how to innovate [66]. Indicators used to measure a company's human resources include the education backgrounds of employees; the professional knowledge of employees; the diversity of employees' backgrounds; the amount of entrepreneurial talent, entrepreneurial spirit, and team spirit of the startup team; the difficulty of recruiting high-quality personnel from outside; and the degree of compliance and rigor of employment [67]. CZB has high requirements for employees' experience, professional ability, responsibility, and hard-working spirit, which guarantee the quality of human resources in CZB. In addition, as a new enterprise, the entrepreneurial team is also an important human resource of CZB in the initial stages. A startup team is a group of people who decide to start a business together after conception [68]. Generally speaking, the entrepreneurial performance of startup teams is better than that of individual entrepreneurs [69]. The core figure of CZB's startup team is the CEO (Chief executive officer), Dai Zhen. Besides him, the core members of the team include the CMO (Chief Marketing Officer), CTO (Chief Technology Officer), and director of human resources. CZB's startup team laid the foundation for success because of the reasonable division of labor and complementary advantages among team members. Therefore, human resources are considered one of the entrepreneurial resources of CZB.

Third, in the context of the internet era, more and more enterprises are applying the platform strategy, integrating various advantageous resources inside and outside the industry through the asset-light mode, improving resource allocation efficiency at the industrial level, and improving the risk and return mechanism of the participants, so as to build a new industry ecology of win-win cooperation [69]. In a previous study, it was found that enterprises that implement an asset-light operation mode have a higher operating efficiency and stronger profitability [70] and can also reduce the volatility of earnings [71]. As an internet platform, CZB also adopts the form of light assets. It basically does not have any physical resources and fixed assets, and needs to obtain a lot of material from external sources to maintain its operation. The gas stations, charging piles, and new energy commercial vehicles required by its main business and secondary business are all indispensable physical resources for its operation, so it is considered that the physical resources are also entrepreneurial resources of CZB.

Finally, as an internet energy platform providing both refueling and charging services for commercial vehicles, China's preference for a new energy policy is also an important entrepreneurial resource of CZB. Environmental regulation has a certain positive impact on the performance improvement of new energy enterprises [72]. The development of CZB's new energy commercial vehicle charging and leasing business has benefited from the introduction of China's policies in recent years, such as the Energy Conservation and New Energy Vehicle Industry Development Plan (2012-2020) and The Three-Years of Action Plan to Win the War of Saving the Blue Sky, issued by the state council of China. Therefore, we conclude that the entrepreneurial resources of CZB include financial resources, human resources, physical resources, and policy resources.

In the next part, we will select the core categories, systematically relate them to other categories, and examine their relationships to form the relationships between constructs and their dimensions, and then construct a theoretical model. 


\section{Findings}

The team members of this study first analyzed and linked the relationships among the core categories and found textual evidence supporting the relationships. Through discussion and examination, it was finally concluded that in the case study demonstrated above, entrepreneurial resources and complementary assets impact platform leadership, while platform leadership affects corporate reputation, and further influences platform sustainability.

\subsection{Relationship between Entrepreneurial Resources and Platform Leadership}

We explored the relationship between the dimensions of entrepreneurial resources and platform leadership through the information reflected in the large amount of textual materials collected, and we found that entrepreneurial resources have an impact on platform leadership. Specifically, capital resources mainly affect the influence and control power of the platform, human resources mainly affect the control power of the platform, physical resources mainly affect the coordination ability of the platform, and policy and legal resources mainly affect the control power of the platform. Specifically relevant evidence is shown in Table 3.

Table 3. Entrepreneurial resources' influence on platform leadership.

\begin{tabular}{|c|c|c|}
\hline Serial Number & $\begin{array}{l}\text { Relationships between } \\
\text { Constructs }\end{array}$ & Reference Statement \\
\hline 1 & $\begin{array}{l}\text { Capital resources and } \\
\text { platform influence power }\end{array}$ & $\begin{array}{l}\text { As the capital frequently favors (capital resources), } \\
\text { injects powerful horsepower into the development of } \\
\text { CZB, making CZB rapidly grow into the "unicorn" of the } \\
\text { "internet + energy" industry (platform influence power). }\end{array}$ \\
\hline 2 & $\begin{array}{l}\text { Capital resources and } \\
\text { platform control power }\end{array}$ & $\begin{array}{l}\text { Through cooperation with three capital companies } \\
\text { (capital resources), CZB's comprehensive strength was } \\
\text { greatly enhanced, and CZB will comprehensively } \\
\text { upgrade in strategic thinking, technological innovation, } \\
\text { product development, organizational structure, company } \\
\text { operation, and other sectors (platform control power). }\end{array}$ \\
\hline 3 & $\begin{array}{l}\text { Human resources and } \\
\text { platform control power }\end{array}$ & $\begin{array}{l}\text { I have never seen such a "crazy team" (human resources) } \\
\text { who can make the big talks come true one by one. This is } \\
\text { the embodiment of innovation control and } \\
\text { implementation power (platform control power). This } \\
\text { company has a vision far beyond our imagination. }\end{array}$ \\
\hline 4 & $\begin{array}{l}\text { Physical resources and } \\
\text { platform coordination } \\
\text { ability }\end{array}$ & $\begin{array}{l}\text { At the energy supply end, CZB has installed more than } \\
200,000 \text { charging piles (physical resources), covering the } \\
\text { whole country, and supporting functions, such as search, } \\
\text { navigation, payment, reservation, and sharing of } \\
\text { charging piles; it has signed contracts with more than } \\
1200 \text { gas stations in China, including Shell, Zhongyuan, } \\
\text { Daqiao petrochemical, and other brands, covering } 26 \\
\text { cities including Beijing, Shanghai, Shenzhen, Zhengzhou, } \\
\text { Suzhou, Xiamen, Chongqing, and Chengdu, realizing the } \\
\text { full coverage of important logistics nodes (platform } \\
\text { coordination ability). }\end{array}$ \\
\hline 5 & $\begin{array}{l}\text { Policy and legal } \\
\text { resources and platform } \\
\text { control power }\end{array}$ & $\begin{array}{l}\text { In first-tier cities, under the background of strict control } \\
\text { of fuel trucks and the development of new energy } \\
\text { logistics, new energy vehicles are the next trend and will } \\
\text { soon to replace diesel or gasoline car(policy and legal } \\
\text { resources), CZB's next focus is on new energy. By } \\
\text { arranging charging piles and after-car service, CZB } \\
\text { gradually guides the owners of fuel logistics vehicles to } \\
\text { transform to new energy logistics vehicles owners } \\
\text { (platform control power). }\end{array}$ \\
\hline
\end{tabular}


Therefore, we derive Proposition 1: Entrepreneurial resources can influence platform leadership. Among them, capital resources have an impact on the platform's influence and control power, human resources have an impact on the platform's control power, physical resources have an impact on the platform's coordination power, and policy and legal resources have an impact on the platform's control power.

\subsection{Relationship between Complementary Assets and Platform Leadership}

We explored the relationships between the dimensions of complementary assets and platform leadership through the information reflected in the large amount of textual materials collected, and we found that complementary assets would affect platform leadership. Among them, the specialized assets mainly influence the platform's control power, and generic assets affect all four dimensions of platform leadership. Specifically relevant evidence is shown in Table 4.

Table 4. Complementary assets' influence on platform leadership.

\begin{tabular}{|c|c|c|}
\hline Serial Number & $\begin{array}{c}\text { Relationships between } \\
\text { Constructs }\end{array}$ & Reference Statement \\
\hline 1 & $\begin{array}{l}\text { Specialized assets and } \\
\text { platform control power }\end{array}$ & $\begin{array}{l}\text { From trying to solve the problem of high fuel cost in the } \\
\text { logistics industry, to building a centralized procurement } \\
\text { platform for commercial vehicles (specialized assets), to } \\
\text { entering the energy big data and energy blockchain and } \\
\text { preparing to build an energy ecological chain, CZB keeps } \\
\text { "upgrading" its business model (platform control power). }\end{array}$ \\
\hline 2 & $\begin{array}{l}\text { Generic assets and } \\
\text { platform leading ability }\end{array}$ & $\begin{array}{l}\text { So far, CZB's APP (Application) has been launched on } \\
\text { Rich, Geely, FAW (First Automobile Workshop, Maxus, } \\
\text { Foton, JAC Motors, and multiple truck models (generic } \\
\text { assets). With less deposit, lower rent, and discounted } \\
\text { charging, CZB is promoting the development of the new } \\
\text { energy market with practical actions (platform leading } \\
\text { ability) and bringing tangible benefits to the owner. }\end{array}$ \\
\hline 3 & $\begin{array}{l}\text { Generic assets and } \\
\text { platform influence power }\end{array}$ & $\begin{array}{l}\text { At present, CZB has established strategic partnerships } \\
\text { with many charging pile operators such as TGOOD, } \\
\text { Wanma New Energy, Winsky New Energy, EV-LINK, } \\
\text { YKCCN, Let's Charge, E-CHARGE, among others } \\
\text { (generic assets) to bring them users and traffic (platform } \\
\text { influence power). }\end{array}$ \\
\hline 4 & $\begin{array}{l}\text { Generic assets and } \\
\text { platform coordination } \\
\text { ability }\end{array}$ & $\begin{array}{l}\text { CZB operates dozens of gas stations in one city (generic } \\
\text { asset). Car owners can see which gas station offers a } \\
\text { large discount in real time through the map. At the same } \\
\text { time, drivers can navigate to the gas station with one } \\
\text { button. When they get to the gas station, they can pay for } \\
\text { the oil with one button and enjoy the discount price. The } \\
\text { overall efficiency will be improved by } 60 \% \text { (platform } \\
\text { coordination ability). }\end{array}$ \\
\hline 5 & $\begin{array}{l}\text { Generic assets and } \\
\text { platform control power }\end{array}$ & $\begin{array}{l}\text { At first, the logistics industry faced high fuel costs and } \\
\text { low average profits. In order to solve this pain point, } \\
\text { CZB set up a "commercial vehicle energy centralized } \\
\text { procurement platform", with one end connected to the } \\
\text { gas station to purchase fuel, and the other end with the } \\
\text { logistics platform cooperation (generic assets), so as to } \\
\text { reduce the fuel cost of commercial vehicles (platform } \\
\text { control power). }\end{array}$ \\
\hline
\end{tabular}

Therefore, we derived Proposition 2: Complementary assets will have an impact on platform leadership, among which, specialized assets will have an impact on platform control power, 
and generic assets will have an impact on the platform's leading ability, influence, coordination ability, and control power.

\subsection{Relationship between Platform Leadership and Platform Reputation}

We explored the relationship between the dimensions of platform leadership and platform reputation through the information reflected in the large amount of textual materials we collected, and we found that platform leadership has an impact on platform reputation. Specifically, a platform's leadership ability and influence mainly affect the cognitive reputation of the platform, while the platform's coordination ability and control power mainly affect the emotional reputation of the platform. Specifically relevant evidence is shown in Table 5.

Table 5. Platform leadership's influence on platform reputation.

\begin{tabular}{cll}
\hline Serial Number & $\begin{array}{c}\text { Relationships between } \\
\text { Constructs }\end{array}$ & \multicolumn{1}{c}{ Reference Statement } \\
\hline & & $\begin{array}{l}\text { As "the world's leading online retailer", "new energy } \\
\text { pioneer", and the service provider of vehicle owner } \\
\text { platform (platform leading ability), CZB won the title of } \\
\text { "2018 top 100 auto internet + innovator of China". It is } \\
\text { ranked at the top of the list, and its leading advantages in } \\
\text { model innovation, growth, investability, and operation } \\
\text { status are highly appraised (cognitive reputation) by } \\
\text { participating automobile enterprises, logistics platforms, } \\
\text { and the expert evaluation committee. }\end{array}$ \\
\hline
\end{tabular}
and the expert evaluation committee.

\begin{tabular}{|c|c|c|}
\hline 2 & $\begin{array}{l}\text { Platform influence power } \\
\text { and cognitive reputation }\end{array}$ & $\begin{array}{l}\text { As the world's leading online energy retailer, depending } \\
\text { on its outstanding contribution in the "internet + energy" } \\
\text { industry, as well as its leading advantages in innovation, } \\
\text { growth, investability, and operation status, CZB won the } \\
\text { title of "king of WISE } 2018 \text { new economy" (cognitive } \\
\text { reputation) in the automotive field. The selection of } \\
\text { "king of new economy" takes "scale" and "high growth } \\
\text { capacity" as basic indicators (platform influence power). }\end{array}$ \\
\hline 3 & $\begin{array}{l}\text { Platform coordination } \\
\text { ability and emotional } \\
\text { reputation }\end{array}$ & $\begin{array}{l}\text { Relying on internet technology, CZB constantly creates a } \\
\text { direct and efficient service matrix to enhance the brand } \\
\text { management service, and quickly realizes the brand } \\
\text { micro operation mode (platform coordination) of } \\
\text { connecting people, things, and scenes with the internet } \\
\text { platform to provide users with a variety of convenient } \\
\text { services and gain a good reputation } \\
\text { (emotional reputation). }\end{array}$ \\
\hline 4 & $\begin{array}{l}\text { Platform control power } \\
\text { and emotional reputation }\end{array}$ & $\begin{array}{l}\text { Wang Mu, a well-known angel investor and founder of } \\
\text { Blue Flame Capital, which is involved in the two rounds } \\
\text { of investment of CZB, said: "Among the commercial } \\
\text { companies I have seen, CZB is a company with industry } \\
\text { monopoly power. I have never seen such a 'crazy team' } \\
\text { that can make the big talks they said come true one by } \\
\text { one (emotional reputation). This is the embodiment of } \\
\text { innovation control and implementation power (platform } \\
\text { control). This company has a vision far beyond } \\
\text { our imagination." }\end{array}$ \\
\hline
\end{tabular}

Therefore, we derived Proposition 3: Platform leadership has an impact on the reputation of platform enterprises, among which, platform leading ability and influence power impact the cognitive reputation and platform coordination ability, and control power impacts the emotional reputation. 


\subsection{Relationship between Platform Reputation and Platform Sustainability}

We explored the relationship between dimensions of platform reputation and platform sustainability through the information reflected in the large amount of textual materials collected, and we found that platform reputation has an impact on platform sustainability. Specifically, platform emotional reputation has an impact on economic performance of the platform, while platform cognitive reputation can influence all three aspects of platform sustainability. The relevant evidence is shown in Table 6.

Table 6. Platform reputation's influence on platform sustainability.

\begin{tabular}{|c|c|c|}
\hline Serial Number & $\begin{array}{c}\text { Relationships between } \\
\text { Constructs }\end{array}$ & Reference Statement \\
\hline 1 & $\begin{array}{l}\text { Cognitive reputation and } \\
\text { economic performance }\end{array}$ & $\begin{array}{l}\text { When you go to the gas station, you can always see that } \\
\text { the drivers are using CZB's APP to refuel (economic } \\
\text { performance). When taking a taxi and asking the drivers } \\
\text { if they know any platform that can save money on } \\
\text { refueling, most of them blurt out CZB, and say that their } \\
\text { friends are also using the platform (cognitive reputation). }\end{array}$ \\
\hline 2 & $\begin{array}{c}\text { Emotional reputation } \\
\text { and economic } \\
\text { performance }\end{array}$ & $\begin{array}{l}\text { "Save money by CZB!", the slogan is now deeply rooted } \\
\text { in the hearts of the drivers, and CZB now has become an } \\
\text { indispensable money-saving device for its users } \\
\text { (emotional reputation). At the same time, CZB business } \\
\text { is also expanding (economic performance). }\end{array}$ \\
\hline 3 & $\begin{array}{l}\text { Cognitive reputation and } \\
\text { environment } \\
\text { stewardship }\end{array}$ & $\begin{array}{l}\text { Recently, the staff of CZB visited many automobile } \\
\text { enterprises and internet platforms at the Changchun } \\
\text { auto show. More than } 60 \% \text { of those who knew about } \\
\text { CZB had experienced its refueling service (cognitive } \\
\text { reputation). Due to the high visibility of CZB, more } \\
\text { enterprises are willing to form a strategic cooperative } \\
\text { relationship with it. CZB improves energy efficiency and } \\
\text { contributes to the promotion of new energy by effectively } \\
\text { integrating the resources of gas stations, and charging } \\
\text { pile suppliers and manufacturers of new energy vehicles } \\
\text { (environment stewardship). }\end{array}$ \\
\hline 4 & $\begin{array}{l}\text { Cognitive reputation and } \\
\text { social wellbeing }\end{array}$ & $\begin{array}{l}\text { Dai Zhen promises that after CZB reaches a certain } \\
\text { degree, he would donate it to the country and make it } \\
\text { more socially beneficial (social wellbeing), as he has long } \\
\text { argued that energy construction is an infrastructure of } \\
\text { the country, and that it is the tens of millions of } \\
\text { commercial vehicle drivers that chose him, that it is the } \\
\text { capital that chose him (cognitive reputation), and that he } \\
\text { is not an entrepreneur, just "hired" by the society for } \\
\text { working in this country. }\end{array}$ \\
\hline
\end{tabular}

Therefore, we derive Proposition 4: A platform's reputation has an impact on the sustainability of platform enterprises, among which, cognitive reputation has an impact on economic performance, environment stewardship, and social wellbeing, while a platform's emotional reputation has an impact on the economic performance of the platform.

To sum up, we propose a relationship between entrepreneurial resources, complementary assets, platform leadership, and platform reputation, as shown in Figure 1. 


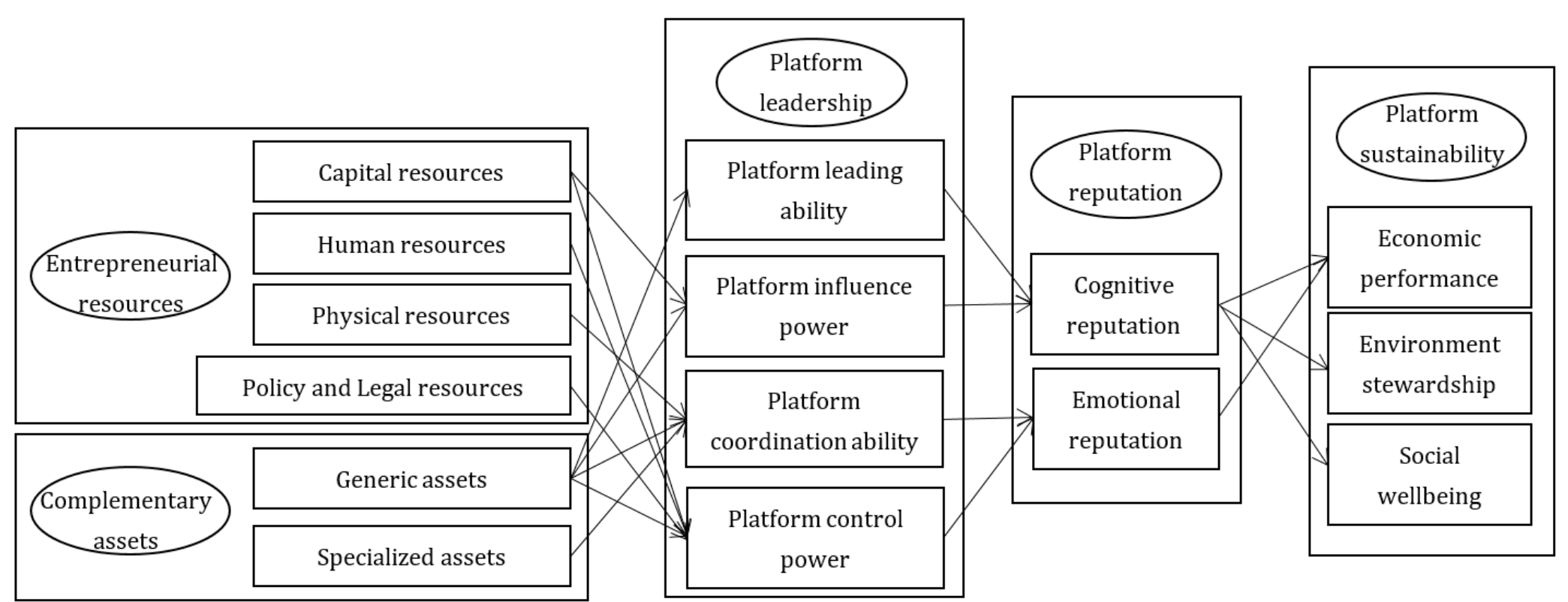

Figure 1. Research model. 


\section{Discussion and Conclusions}

The business model of platform enterprises refers to a business model that connects a number of specific groups and provides them with an interactive mechanism to meet the needs of all groups and skillfully profit from them [36]. Platform enterprises themselves do not own many assets [28]. Therefore, for platform enterprises, the identification and application of entrepreneurial resources and the acquisition of complementary assets are closely related to the improvement of platform leadership and its reputation, and further influence its sustainability. Based on a single case study analysis, by using grounded theory, we explored the linkages among entrepreneurial resources, complementary assets, platform leadership, and the reputation and sustainability of platform enterprises and established a relational model that can be applied to the practice of platform enterprises.

Our paper makes the following contributions: There is much research focused on the relationship between entrepreneurial resources and enterprise sustainability $[73,74]$ and the impact of complementary assets on enterprise sustainability $[75,76]$. However, there is a lack of research involving the impact of platform leadership and corporate reputation in the relationship between entrepreneurial resources, complementary assets, and platform sustainability. By adopting grounded theory method, we conducted a single case analysis of a Chinese successful start-up, CZB, and demonstrated the relationship between entrepreneurial resources, complementary assets, platform leadership, platform reputation, and platform sustainability, which complement the existing literature on entrepreneurship and sustainability.

The results show that entrepreneurial resources and complementary assets will further influence platform reputation by influencing its leadership, and ultimately play an important role in influencing platform sustainability. This paper demonstrates how entrepreneurial resources and complementary assets affect platform leadership, as well as platform reputation, and, furthermore, how these factors affect platform sustainability, laying the foundation for further quantitative analysis. In addition, the survival of emerging platform enterprises are threatened by various uncertainties. To expand business, enterprises usually take steps to acquire entrepreneurial resources and to integrate complementary assets. Our research shows, besides these steps, quickly upgrading platform leadership and its reputation is the key to platform sustainability.

However, our research still has some limitations. First of all, we adopted a single case study, and the importance of entrepreneurial resources and complementary assets may vary among different enterprises. We did not use a further multi-case analysis to supplement and modify the model, so the accuracy of the model may be slightly biased. Secondly, because of limited objective conditions, we did not explore the relationship between complementary assets and entrepreneurial resources; the relationship between complementary assets and corporate reputation; the relationship between entrepreneurial resources and corporate reputation; and the impacts of entrepreneurial resources, complementary assets, and platform leadership on platform sustainability. We hope to make up for the limitations above in future studies.

Author Contributions: J.G. supervised the work. T.L. and J.X.G. collected the data, carried out the study, and wrote the paper, with contributions from J.G. and T.L. All authors read and approved the final manuscript.

Funding: Project: Research on Course Design and Development of Entrepreneurial Resources for MOOC (Massive Open Online Courses). Project Code: CY 16201. Sponsor: China Higher Education Student Information and Career Centre.

Acknowledgments: The authors are thankful to CZB's internal staff for providing us with the interview materials. The authors are thankful to the staff and students from the Business School of Central University of Finance and Economics for their efforts in data collection, collation, and coding.

Conflicts of Interest: The authors declare that they have no conflict of interest. 


\section{References}

1. Lee, S.M.; Kim, T.; Noh, Y.; Lee, B. Success factors of platform leadership in web 2.0 service business. Serv. Bus. 2010, 4, 89-103. [CrossRef]

2. Perrons, R.K. The open kimono: How Intel balances trust and power to maintain platform leadership. Res. Policy 2009, 38, 1300-1312. [CrossRef]

3. Yoffie, D.B.; Gawer, A.; Cusumano, M.A. A Study of More Than 250 Platforms Reveals Why Most Fail. Harv. Bus. Rev. 29 May 2019. Available online: https://hbr.org/2019/05/a-study-of-more-than-250-platformsreveals-why-most-fail (accessed on 9 August 2019).

4. Gawer, A.; Henderson, R.M. Platform Owner Entry and Innovation in Complementary Markets: Evidence from Intel. J. Econ. Manag. Strategy 2007, 16, 1-34. [CrossRef]

5. Zhang, Y.; Liu, R.H. Research on the Relationship among Complementary Assets, Platform Leadership and Ambidextrous Innovation. Sci. Technol. Prog. Policy 2019, 6, 1-8. Available online: http://kns.cnki.net/kcms/ detail/42.1224.G3.20190309.0936.042.html (accessed on 28 April 2019).

6. Barney, J. Firm Resources and Sustained Competitive Advantage. J. Manag. 1991, 17, 99-120. [CrossRef]

7. Wernerfelt, B. A resource-based view of the firm. Strateg. Manag. J. 1984, 5, 171-180. [CrossRef]

8. Yang, X.; Sun, S.L.; Zhao, X. Search and execution: Examining the entrepreneurial cognitions behind the lean startup model. Small Bus. Econ. 2019, 52, 667-679. [CrossRef]

9. Muegge, S. Platforms, Communities, and Business Ecosystems: Lessons Learned about Technology Entrepreneurship in an Interconnected World. Technol. Innov. Manag. Rev. 2013, 3, 171-179. [CrossRef]

10. Wartick, S.L. The Relationship between Intense Media Exposure and Change in Corporate Reputation. Bus. Soc. 1992, 31, 33-49. [CrossRef]

11. Wei, J.; Ouyang, Z.; Chen, H.A. Well Known or Well Liked? The Effects of Corporate Reputation on Firm Value at the Onset of a Corporate Crisis. Strateg. Manag. J. 2017, 38, 2103-2120. [CrossRef]

12. Schwaiger, M. Components and Parameters of Corporate Reputation-An Empirical Study. Schmalenbach Bus. Rev. 2004, 5, 46-71. [CrossRef]

13. Liu, Y.Y.; Lou, Z.; Liu, J.; Song, J.W. The Influencing Factors of Corporate Reputation and its Impact on Consumers' Word-of-Mouth Behavior. Chin. J. Manag. 2009, 6, 348-389.

14. Lin, J.Z. An Empirical Analysis on Reputation System in Online Shopping Platform based on Buyers' Perception. China Bus. Mark. 2016, 30, 70-78.

15. Wang, X.H.; Zhang, Q.L. The Construction of the E-commerce Platform Reputation: From the Perspective of the Value Co-creation between Platform Enterprise and Sellers. China Ind. Econ. 2017, 11, 176-194.

16. Lee, K.H. Linking stakeholders and corporate reputation towards corporate sustainability. Int. J. Innov. Sustain. Dev. 2012, 6, 219-235. [CrossRef]

17. Rensburg, R.; Beer, E.D.; Coetzee, E. Linking Stakeholder Relationships and Corporate Reputation: A Public Relations Framework for Corporate Sustainability. In Public Relations Research; VS Verlag für Sozialwissenschaften: Berlin, Germany, 2008; pp. 385-396.

18. Kraaijenbrink, J.; Spender, J.C.; Groen, A.J. The Resource-Based View: A Review and Assessment of its Critiques. J. Manag. 2010, 36, 349-372. [CrossRef]

19. Lin, S. The Acquisition and Integration of Entrepreneurial Resources-A Perspective of the Entrepreneurial Process. Inq. Econ. Issues 2007, 6, 166-169.

20. Yu, S.Z. The Effect of Entrepreneurial Resource on Entrepreneurial Performance: Based on Moderating Mechanism of Environmental Dynamism. Sci. Sci. Manag. S. T. 2013, 34, 131-139.

21. Lin, S.; Zhang, W.; Lin, Q. A Study on the Framework of Assembling Resources in Hi-Tech New Ventures. Sci. Sci. Manag. S. T. 2005, 26, 143-147.

22. Pan, A.C. Jiaoqing Behaviors and Entrepreneurial Opportunity: A Multi-case Study on Agricultural Entrepreneurship. J. Manag. Sci. 2014, 27, 59-75.

23. Sarma, S.; Sun, S.L. The genesis of fabless business model: Institutional entrepreneurs in an adaptive ecosystem. Asia Pac. J. Manag. 2016, 34, 587-617. [CrossRef]

24. Sun, S.L.; Zhang, Y. Qihoo 360: Building a "free" business model. Case J. 2015, 11, 163-183. [CrossRef]

25. Grant, R.M. The Resource-Based Theory of Competitive Advantage: Implications for Strategy Formulation. Calif. Manag. Rev. 1991, 33, 114-135. [CrossRef] 
26. Teece, D.J. Profiting from Technological Innovation: Implications for Integration, Collaboration, Licensing and Public Policy. Res. Policy 1986, 15, 285-305. [CrossRef]

27. Luo, M.; Zhao, H.M. Secrets of Made in China: Innovation plus Complementary Assets. China Ind. Econ. 2009, 5, 46-56.

28. Gawer, A.; Cusumano, M.A. Platform Leadership: How Intel, Microsoft, and Cisco Drive Industry Innovation; Harvard Business School Press: Boston, MA, USA, 2002.

29. Ceccagnoli, M.; Graham, S.J.; Higgins, M.J.; Lee, J. Productivity and the Role of Complementary Assets in Firms' Demand for Technology Innovations. Ind. Corp. Chang. 2010, 19, 839-869. [CrossRef]

30. Eckhardt, J.T.; Shane, S.A. Industry changes in technology and complementary assets and the creation of high-growth firms. J. Bus. Ventur. 2011, 26, 412-430. [CrossRef]

31. Podolny, J.; Page, K.L. Network forms of organization. Annu. Rev. Sociol. 1998, 24, 57-76. [CrossRef]

32. Müller-Seitz, G. Leadership in interorganizational networks: A literature review and suggestions for future research. Int. J. Manag. Rev. 2011, 14, 428-443. [CrossRef]

33. Beyer, J.M.; Browning, L.D. Transforming an Industry in Crisis: Charisma, Routinization, and Supportive Cultural Leadership. Leadersh. Q. 1999, 10, 483-520. [CrossRef]

34. Cusumano, M.A.; Gawer, A. The elements of platform leadership. IEEE Eng. Manag. Rev. 2003, 43, 51-58. [CrossRef]

35. Boudreau, K. Too Many Complementors? Evidence on Software Developers. 2008; Unpublished work.

36. Chen, W.R.; Yu, Z.X. Platform Strategy: Business Model in Revolution; China Citic Press: Beijing, China, 2013.

37. Fombrun, C.J. Reputation: Realizing Value from the Corporate Image; Harvard Business School Press: Boston, MA, USA, 1996.

38. Lange, D.; Lee, P.M.; Dai, Y. Organizational reputation: A review. J. Manag. 2011, 37, 153-184. [CrossRef]

39. Weigelt, K.; Camerer, C.F. Reputation and Corporate Strategy: A Review of Recent Theory and Applications. Strateg. Manag. J. 1988, 9, 443-454. [CrossRef]

40. Bundy, J.; Pfarrer, M.D. A burden of responsibility: The role of social approval at the onset of a crisis. Acad. Manag. Rev. 2015, 40, 345-369. [CrossRef]

41. Dierickx, I.; Cool, K. Asset Stock Accumulation and Sustainability of Competitive Advantage. Manag. Sci. 1989, 35, 1504-1511. [CrossRef]

42. Fombrun, C.; Shanley, M. What's in a Name? Reputation Building and Corporate Strategy. Acad. Manag. J. 1990, 33, 233-258.

43. Gioia, D.A.; Schultz, M.; Corley, K.G. Organizational Identity, Image, and Adaptive Instability. Acad. Manag. Rev. 2000, 25, 63-81. [CrossRef]

44. Celetani, M.; Fudenberg, D.; Levine, D.K.; Pesendorfer, W. Maintaining a Reputation Against a Long-Lived Opponent. Econom. J. Econom. Soc. 1996, 64, 691. [CrossRef]

45. Herremans, I.M.; Akathaporn, P.; Mcinnes, M. An investigation of corporate social responsibility reputation and economic performance. Account. Organ. Soc. 1993, 18, 587-604. [CrossRef]

46. Roberts, P.W.; Dowling, G.R. Corporate Reputation and Sustained Superior Financial Performance. Strateg. Manag. J. 2002, 23, 1077-1093. [CrossRef]

47. Vergin, R.C.; Qoronfleh, M.W. Corporate reputation and the stock market. Bus. Horiz. 1998, 41, $19-26$. [CrossRef]

48. Greif, A. Reputation and Coalitions in Medieval Trade: Evidence on the Maghribi Traders. J. Econ. Hist. 1989, 49, 857. [CrossRef]

49. Orlitzky, M.; Benjamin, J.D. Corporate Social Performance and Firm Risk: A Meta-Analytic Review. Bus. Soc. 2001, 40, 369-396. [CrossRef]

50. Czinkota, M.; Kaufmann, H.R.; Basile, G. The relationship between legitimacy, reputation, sustainability and branding for companies and their supply chains. Ind. Mark. Manag. 2014, 43, 91-101. [CrossRef]

51. Chun, R.; Davies, G. The Influence of Corporate Character on Customers and Employees: Exploring Similarities and Differences. J. Acad. Mark. Sci. 2006, 34, 138-146. [CrossRef]

52. Gardberg, N.A.; Fombrun, C.J. For Better or Worse-The Most Visible American Corporate Reputations. Corp. Reput. Rev. 2002, 4, 385-391. [CrossRef]

53. Hall, R. The Strategic Analysis of Intangible Resources. Strateg. Manag. J. 1992, 13, 135-144. [CrossRef]

54. Sharma, S.; Henriques, I. Stakeholder influences on sustainability practices in the Canadian forest products industry. Strateg. Manag. J. 2005, 26, 159-180. [CrossRef] 
55. Dyllick, T.; Hockerts, K. Beyond the Business Case for Corporate Sustainability. Bus. Strategy Environ. 2002, 11, 130-141. [CrossRef]

56. Bansal, P. Evolving sustainably: A longitudinal study of corporate sustainable development. Strateg. Manag. J. 2005, 26, 197-218. [CrossRef]

57. Young, W.; Tilley, F. Can businesses move beyond efficiency? The shift toward effectiveness and equity in the corporate sustainability debate. Bus. Strategy Environ. 2010, 15, 402-415. [CrossRef]

58. Carroll, A.B. The Pyramid of Corporate Social Responsibility: Toward the Moral Management of Organizational Stakeholders. Bus. Horiz. 1979, 34, 39-48. [CrossRef]

59. Wood, D.J. Corporate Social Performance Revisited. Acad. Manag. Rev. 1991, 16, 691-718. [CrossRef]

60. Strass, A.; Corbin, J. Basics of Qualitative Research: Techniques and Procedures for Developing Ground Theory; Sage: Thousand Oaks, CA, USA, 1998.

61. Dong, Z.Y.; Zhao, J.H.; Wen, F.S.; Xue, Y. From Smart Grid to Energy Internet: Basic Concept and Research Framework. Autom. Electr. Power Syst. 2014, 38, 1-11.

62. Rifkin, J. The Third Industrial Revolution: How Lateral Power is Transforming Energy, the Economy, and the World; Macmillan: London, UK, 2011.

63. Liu, B.; Chen, S. Opportunities and Business Models of China's Energy Internet Industry. Enterp. Manag. 2018, 6, 24-28.

64. Official Website of CZB. Available online: https://www.czb365.com/ (accessed on 28 April 2019).

65. Yang, F.C. Optimising Resource Portfolio Planning for Capital-Intensive Industries Under Process-Technology Progress. Int. J. Prod. Res. 2009, 47, 2625-2648. [CrossRef]

66. Ployhart, R.E.; Moliterno, T.P. Emergence of the Human Capital Resource: A Multilevel Model. Acad. Manag. Rev. 2011, 36, 127-150. [CrossRef]

67. Kamm, J.B.; Shuman, J.C.; Seeger, J.A.; Nurick, A.J. Entrepreneurial teams in new venture creation: A research agenda. Entrep. Theory Pract. 1990, 14, 7-17. [CrossRef]

68. Cooper, A.C.; Bruno, A.V. Success among high-technology firms. Bus. Horiz. 1977, 20, 16-22. [CrossRef]

69. Wang, Y.Q.; Chen, J.L. Study on the Integration Mode of Traditional Manufacturing under the Strategy of Light Assets Operation: Based on Internet Perspective. J. Huaqiao Univ. 2018, 5, 61-72, 80.

70. Lin, C.S.; Huang, C.P. Measuring competitive advantage with an asset-light valuation model. Afr. J. Bus. Manag. 2011, 5, 5100-5108.

71. Sohn, J.; Tang, C.H.; Jang, S.C. Does the asset-light and fee-oriented strategy create value? Int. J. Hosp. Manag. 2013, 32, 270-277. [CrossRef]

72. Li, Z.X.; Yang, Y. The Impact of Environmental Regulation Policies on the Performance of Energy Enterprises-Evidence form Thermal Power Generation Enterprises. Finance Account. Mon. 2011, 11, 55-58.

73. Learned, K.E.; Stewart, A. Entrepreneurial Capabilities and Resources: Sustainable Competitive Advantage through Innovation and Opportunism; United States Association for Small Business and Entrepreneurship: Whitewater, WI, USA, 1992.

74. Mcwilliams, A.; Siegel, D.S. Creating and Capturing Value: Strategic Corporate Social Responsibility, Resource-Based Theory, and Sustainable Competitive Advantage. J. Manag. 2011, 37, 1480-1495. [CrossRef]

75. Helfat, C.E. Know-How and Asset Complementarity and Dynamic Capability Accumulation: The Case of R \& D. Strateg. Manag. J. 1997, 18, 339-360.

76. Woo, C.; Chung, Y.; Chun, D.; Seo, H. Exploring the Impact of Complementary Assets on the Environmental Performance in Manufacturing SMEs. Sustainability 2014, 6, 7412-7432. [CrossRef]

(C) 2019 by the authors. Licensee MDPI, Basel, Switzerland. This article is an open access article distributed under the terms and conditions of the Creative Commons Attribution (CC BY) license (http://creativecommons.org/licenses/by/4.0/). 